\title{
Pay-as-you-go trials anger government cancer researchers
}

\section{Washington}

Biotherapeutics Inc., a newly established cancer research company based in Franklin, Tennessee, is attracting favourable interest on the stock market. But is also at the centre of a vigorous debate over research ethics. Through its associated clinical centres, Biotherapeutics allows terminally ill cancer patients to participate in clinical trials of experimental therapies - at a price. Critics contend that charging for access to clinical trials is unethical exploitation.

The therapies are all legitimate experimental treatments; many are also being investigated at other clinical centres, and those that require approval from the Food and Drug Administration (FDA) have it. They include monoclonal antibody immunoconjugate 'cocktails' tailored to the individual patient, use of lymphokineactivated killer (LAK) cells (the technique pioneered by Dr Steven Rosenberg at the National Cancer Institute) and production of autologous tumour vaccines.

Louis Berneman, Biotherapeutics' president, argues that the company is simply selling research services, albeit research geared to individual patients. Once a patient's tumour has been characterized in Biotherapeutics' laboratories, experimental treatments that may be possible are then investigated in standard clinical trials conducted by a separate not-forprofit clinical research organization. Patients gain access to experimental therapies, and pharmaceutical companies obtain free trial data that can be used to support applications to FDA for generaluse permits. The data are also published in the scientific literature

Critics argue, however, that the company's claim to be merely conducting research is disingenuous. One prominent critic is Dr Vincent T. DeVita, director of NCI. DeVita says he "would be interested to hear what discoveries" the company has made in the course of its research. He believes it unethical to sell access to clinical trials, and claims that Biotherapeutics merely takes experimental protocols developed elsewhere and offers them to a vulnerable public before they have been adequately validated. He points out that the therapies are not harmless (at NCI, some patients died as a result of LAK therapy side-effects). And he claims that NCI makes new treatments available to the public as fast as is prudent.

Others believe that if Biotherapeutics is filling a market need its activities are justified: demand for places in clinical trials in more orthodox settings clearly outstrips supply. The company has given about 100 patients LAK cell therapy, second only to
NCI, where about 150 have been treated, according to Berneman. Although over 2,000 patients have been referred there in the 18 months since its doors opened, only 200 have been accepted, which De Vita says may be too selective to apply to the general population.

The therapies are expensive $-\$ 19,000$ for LAK treatment, for example. But Biotherapeutics points out that this is much less than the estimated $\$ 100,000$ it cost NCI to provide similar treatment. And the company rejects the suggestion that it only takes experimental protocols from elsewhere: it claims to have made improvements to Rosenberg's original scheme for production of LAK cells that have reduced the incidence of toxic sideeffects while retaining efficacy. One third of LAK patients have shown improvements by standard criteria (50 per cent reduction in tumour size), similar to Rosenberg's success rate, according to

Berneman. Good results have now been seen in at least eight tumour types, including lymphomas, and Berneman says equally encouraging results will soon be reported using monoclonal antibody immunoconjugate cocktails. Berneman claims Biotherapeutics is unique in offering such tailor-made cocktails.

It may be a measure of investor interest that Biotherapeutics is the only healthcare company to make a public offering in 1986 that is still trading above its offering price. It will shortly conclude the second phase of a financing that will raise a total of about $\$ 35$ million: Berneman says investors are optimistic because the company reduces the element of chance associated with cancer therapies: "whichever of the pharmaceutical companies wins, we win". Collaborative research agreements have recently been concluded with pharmaceutical manufacturers for supply of radioisotopes and of tumour antigens for preclinical testing, and Biotherapeutics intends to establish a nationwide network of laboratories. Biotherapeutics is charting an original course, but it seems likely that others will follow.

Tim Beardsley

\section{French science policy balances on the scales of political debate}

\section{London}

THE future of French science policy - and of French higher education in general - is in the balance, with the abandonment of Prime Minister Jacques Chirac's attempt to reform the universities and the consequent resignation of the research and universities minister, physicist Alain Devaquet. At the same time, President François Mitterrand has overtly declared his unprecedented support of science and

\section{IMAGE UNAVAILABLE FOR COPYRIGHT REASONS}

Mitterrand (left) and Chirac - rivals for popularity on the science battleground (AP).

technology. This is bad news for Chirac, who had been preparing himself for the presidential elections, which must take place before May 1988, but earlier if Mitterand, who is now riding high in public opinion, so decides.

What effect these events will have on research and technology in France is not at all clear. In the immediate future, Chirac appears to be taking an extraordinarily long time in replacing his science minister, which indicates that a battle is taking place in the cabinet over control.

There may be a hope for the re-creation of a research and technology ministry, with the universities left with education, but this seems unlikely as it would take back from the industry ministry control of many of the technology sectors.

Meanwhile Mitterrand is revelling in his new popularity, and was using it very recently to support both the students and science and technology as the elements in the politics and economics of France and Europe. In a strong speech at La Villette, the vast new Paris exhibition of science and technology, Mitterrand declared his commitment to research and education.

He outlined a policy of strengthening links between university and industry, encouraging innovation, supporting industrial research; of developing a strategy for scientific training, employment and mobility; of using the diversity of the French education system to the full by linking one sector better with another rather than challenging either "to cultivate their differences and synergy"; of linking public and private research institutions.

Mitterand also said "the research economy requires greater and greater expenditure... it is truly urgent that Europe appeal to its own resources of the first rank, and use its veins of intelligence and knowledge.... The European Community has done its apprenticeship in research cooperation, and learnt how to manage such programmes effectively." These efforts must now be expanded.

Robert Walgate 